Kansas State University Libraries

New Prairie Press

Academic Chairpersons Conference

37th Academic Chairpersons Conference, Proceedings

\title{
The Introvert's Guide to Chairing the Department
}

Jeff Buller

Florida Atlantic University, jeffbuller@mac.com

Follow this and additional works at: https://newprairiepress.org/accp

Part of the Educational Leadership Commons, and the Higher Education Administration Commons (c) (i) (2)

This work is licensed under a Creative Commons Attribution-Share Alike 4.0 License.

\section{Recommended Citation}

Resources Ancowitz, N. (2010). Self-promotion for introverts: The quiet guide to getting ahead. (n.p.): McGraw Hill. Badaracco, J. L., Jr. (2002). Leading quietly: An unorthodox guide to doing the right thing. Boston, MA: Harvard Business School Publishing. Cain, S. (2012). Quiet: The power of introverts in a world that can't stop talking. New York, NY: Broadway Books. Granneman, J. (2017). The secret lives of introverts: Inside our hidden world. New York, NY: Skyhorse Publishing. Kahnweiler, J. B. (2013). Quiet influence: The introvert's guide to making a difference. San Francisco, CA: Berrett-Koehler Publishers, Inc. Kahnweiler, J. B. (2013). The introverted leader: Building on your quiet strength. Oakland, CA: BerrettKoehler Publishers, Inc. Laney, M. O. (2002). The introvert advantage: How quiet people can thrive in an extrovert world. New York, NY: Workman Publishing Company, Inc. Smith, M. J. (1975). When I say no, I feel guilty. New York, NY: Bantam Books. Vavrichek, S. M. (2012). The guide to compassionate assertiveness: How to express your needs \& deal with conflict while keeping a kind heart. Oakland, CA: New Harbinger Publications, Inc. Zack, D. (2010). Networking for people who hate networking: A field guide for introverts, the overwhelmed, and the underconnected. Oakland, CA: Berrett-Koehler Publishers, Inc.

This Event is brought to you for free and open access by the Conferences at New Prairie Press. It has been accepted for inclusion in Academic Chairpersons Conference Proceedings by an authorized administrator of New Prairie Press. For more information, please contact cads@k-state.edu. 
Most leadership training programs assume that all leaders are or should be extraverts. In fact, most leadership books suggest a close overlap between the qualities of extraverts and the most desirable traits of leaders, like sociability, accessibility, and support for an open-door policy. But a significant portion of the faculty, staff, and administration in higher education consists of introverts. How are these introverts to succeed in leadership positions? In this workshop, a lifelong and confirmed introvert (who is also a proven academic leader) explains how.

We will provide an inventory that allows participants to assess where they fall on an introversion/extraversion scale. Then we will discuss how introverts can play to their strengths, how and when to use their "learned extraversion" traits, and how to balance their departmental team for maximum impact.

The workshop should appeal to any chair or academic leader who wonders if he or she might be an introvert as well as those who work alongside introverts and want to know how to interact with them most successfully. 